УДК 378.147(045)

Віталій Рахманов,

доктор педагогічних наук, доцент Національний університет оборони України імені Івана Черняховського, м. Київ

ORCID ID 0000-0002-7180-4087

Сергій Ясенко

кандидат технічних наук, доцент Національний університет оборони України імені Івана Черняховського, м. Київ

ORCID ID 0000-0003-1918-9459

DOI: 10.33099/2617-1775/2021-02/194-204

\title{
УДОСКОНАЛЕННЯ ОСВІТНЬОЇ ДІЯЛЬНОСТІ ДЛЯ КАДРОВОГО МЕНЕДЖМЕНТУ В ЗБРОЙНИХ СИЛАХ УКРАЇНИ
}

У статті розглядаються пропозииї щодо забезпечення якісним персоналом Збройних Сил України, удосконалення освітньої діяльності у контексті оборонної, кадрової та інших реформ, з урахуванням сучасних міжнародних та військових факторів, які впливають на формування дієздатності Збройних Сил Украӥни. Основну увагу зосереджено на формуванні кадрового менеджменту в ЗСУ. У статті закцентовано увагу на тому, що на вітчизняному ринку праці тривалий час формувалася низька конкурентоспроможність військової сфери внаслідок недосконалої системи соціальних гарантій військовослужбовиів та членів їхніх сімей, відсутності впевненості щуодо перспектив професійного та кар'єрного зростання, щзо в кінцевому випадку може призвести до дестабілізації ситуаиії в Збройних Силах Украӥни та відокремлення з них найбільш досвідчених та підготовлених військових фахівців. У статті зроблено висновок про те, щзо подальших досліджень потребують онтологічна модель системи професійної військової освіти, опис логічно-ієрархічної моделі освітніх спроможностей, підходи до адаптачії сучасних освітніх технологій до потреб військової сфери, архітектурна модель та реалізачія архітектурного циклу щуодо системи військової освіти з врахуванням відповідних моделей НАТО та країн-партнерів, аналіз та адаптація сучасних практик кадрового менеджменту розвинутих краӥн до відповідної ситуації у сфері оборони в Україні.

Ключові слова: кадровий менеджмент; освітня діяльність; оборонна реформа; професійна військова освіта; системний підхід.

Постановка проблеми. Оцінка стану воєнної безпеки держави, а також набутий досвід участі ЗСУ в антитерористичній операції, виявили низку проблем функціонування сил оборони в умовах існуючих та потенційних загроз, що дозволило визначити напрями, мету та механізми оборонної реформи в Україні. Таким чином, метою оборонної реформи $\epsilon$ розвиток (відповідно до євроатлантичних норм та критеріїв членства в НАТО) спроможностей Міністерства оборони України, Збройних Сил України та інших складових сил оборони, необхідних для швидкого реагування на загрози національній безпеці у воєнній сфері, захисту України, іiі суверенітету, територіальної цілісності та непорушності (недоторканності) кордонів, підтримки міжнародного миру та безпеки $[1,7]$.

У цьому контексті зростає потреба в запровадженні нових науково обгрунтованих засад державної кадрової політики як державного кадрового менеджменту у військовій сфері. Головна мета та зміст кадрової політики 
зумовлюють необхідність в удосконаленні системи управління персоналом $[3,4]$.

Аналіз останніх досліджень і публікацій. Розгляду проблем розвитку системи управління персоналом та державної кадрової політики присвячені праці зарубіжних і вітчизняних фахівців: М. Армстронга, М. Альберта, Г. Бекера, К. Вайса, Е. Ведунга, а також В. Андрушка, В. Бакуменка, М. Білинської, О. Боровського, Н. Гончарук, Н. Грицяк, С. Дубенко, В. Князєва, О. Крушельницької, В. Лугового, А. Михненка, Н. Нижник, Т. Пахомової, А. Рачинського, I. Розпутенка, С. Серьогіна, В. Трощинського тощо.

Серед основних документів, які складають правову основу кадрового менеджменту у військовій сфері та визначають напрями його реформування, слід відзначити Конституцію України та закони України [5], Стратегію національної безпеки України, яка затверджена указом Президента України від 14 вересня 2020 року № 392/2020 [13], Стратегічний оборонний бюлетень України (далі - Стратегічний бюлетень), затверджений указом Президента України від 17 вересня 2021 року № 473/2021 [14], міжнародні договори України, а також інші нормативно-правові документи $[8,9,10,11]$.

Стратегічний бюлетень спрямований на забезпечення практичної реалізації воєнної політики України в контексті всеохоплючої оборони України, перспективну модель Збройних Сил України та інших складових сил оборони, вимоги до їх побудови (включно місією, візією сил оборони зразка 2030 року), необхідні спроможності сил оборони, стратегічні цілі розвитку сил оборони до 2025 року, основні завдання та очікувані результати їх досягнення.

Мета статті полягає у розкритті пропозиції щодо забезпечення якісним персоналом у Збройних Силах України, удосконаленні освітньої діяльності в контексті оборонної, кадрової та інших реформ, з урахуванням сучасних міжнародних та військових факторів, які впливають на формування дієздатної армії України.

Виклад основного матеріалу. Метою проведення оборонної реформи в Україні є набуття та підтримання силами оборони необхідного рівня бойової готовності та здатності до виконання завдань оборони держави (оборонних спроможностей), ефективного реагування на виникаючі воєнні загрози та воєнно-політичні виклики національній безпеці, підвищення рівня оперативної сумісності Збройних Сил України та інших військових формувань 3 підрозділами збройних сил держав-членів НАТО та ЄС до виконання спільних завдань в міжнародних операціях із підтримання миру i безпеки [7]. Відзначається, що протягом 2016 - 2020 років окремі ключові завдання оборонної реформи виконано, наприклад щодо:

1. Об'єднаного керівництва силами оборони, що здійснюється відповідно

до принципів і стандартів, прийнятих державами-членами НАТО;

2. Ефективної політики системи планування і управління ресурсами в секторі оборони з використанням сучасних євроатлантичних підходів;

3. Оперативних (бойових, спеціальних) спроможностей сил оборони, необхідних для гарантованої відсічі збройній агресії, оборони держави, підтримання миру та міжнародної безпеки; 
4. Об'єднаної системи логістики і системи медичного забезпечення, здатних надати підтримку всім компонентам сил оборони;

5. Професіоналізації сил оборони та створення необхідного військового резерву.

Разом 3 тим визнано, що наявний стан сектору оборони потребує послідовного продовження оборонної реформи через недостатні спроможності сил оборони реагувати на поточні чи перспективні загрози, що проявляються у різних формах та у різний спосіб щодо окремих напрямків діяльності (кібербезпека/кібероборона, логістика та медичне забезпечення, територіальна оборона тощо).

Практично, Стратегічний оборонний бюлетень направлений на уточнення та реалізацію положень Стратегії воєнної безпеки, яка визначила такі основні напрямки реалізації державної політики у воєнній сфері, сферах оборонного і військового будівництва:

- обороні спроможності держави, в поєднанні 3 консолідованим міжнародним тиском на Російську Федерацію;

- ефективний менеджмент у сфері оборони, заснований на засадах демократичного цивільного контролю, інших принципах і стандартах НАТО, інноваційних рішеннях та сучасних бізнес-практиках, програмно-проєктному управлінні оборонними ресурсами, удосконалених процесах визначення та задоволення потреб оборони;

- професіоналізація діяльності (персоналу) Збройних Сил України та інших складових сил оборони;

- підвищення технологічності озброєння і військової техніки Збройних Сил України та інших складових сил оборони, яка забезпечує виконання ними покладених завдань, у тому числі спільно з відповідними структурами державчленів НАТО;

- забезпечення взаємосумісності з відповідними структурами державчленів НАТО сил оборони.

3 урахуванням типової структури спроможності прийнятій в Україні, такої що відповідає моделі DOTMLPFI HATO, кожен $з$ напрямів та пріоритетів оборонної політики безпосередньо пов'язаний з формуванням відповідного кадрового потенціалу, механізмами залучення високопрофесійних службовців як на вищому рівні, так й інших ланках ЗСУ, стосується різних аспектів управління людськими ресурсами у військовій сфері. Але 3 викладеного можна побачити, що трансформація системи кадрового менеджменту в ЗСУ виділена в окремий пріоритет - професіоналізацію сил оборони та створення необхідного військового резерву [6]. Цей пріоритет $є$ не тільки необхідною умовою для формування якісного кадрового потенціалу Збройних Сил України, інших складових сил оборони, комплектування їх підготовленим та мотивованим особовим складом, а й однією з вимог відповідності військової сфери критеріям та показникам НАТО.

Запланованим результатом реалізації воєнної політики є формування в Україні необхідного кадрового потенціалу Збройних Сил та інших складових сил оборони професійно підготовленими, 3 високими морально-діловими 
якостями військовослужбовцями, здатними якісно вирішувати складні військово-професійні завдання у мирний час та особливий період; сили оборони будуть укомплектовані підготовленим та мотивованим особовим складом; буде створено та підготовлено стратегічний резерв Збройних Сил України, здатний здійснювати наступальні (контрнаступальні) дії, посилювати угруповання військ (сил) на загрозливих напрямах, забезпечувати ротацію військ (сил), їх поповнення та заміну на випадок втрати боєздатності, тому основними оперативними цілі для досягнення пріоритету існує:

- розвиток соціально-гуманітарного забезпечення персоналу; удосконалення системи військової освіти та підготовки кадрів;

- реформування системи мобілізації та створення військового резерву;

- створення сучасної системи кадрового менеджменту.

3 урахуванням основних чинників (складників) ефективного менеджменту у сфері оборони (демократичний цивільний контроль, інші принципи i стандарти НАТО, інноваційні рішення та сучасних бізнес-практиках, програмно-проєктному управлінні оборонними ресурсами, удосконалених процесах визначення та задоволення потреб оборони) очікується, що буде змінено образ мислення особового складу в напрямі європейських цінностей; рівень матеріального та інших видів забезпечення військовослужбовців приведено у відповідність 3 умовами проходження служби; система професійної військової освіти має набути практичного спрямування навчання, впроваджено в навчальний процес передові методики підготовки збройних сил держав-членів HATO. 3 огляду на згадану вище DOTMLPFI-модель, складник L (Лідерство) на стратегічному рівні реалізують через пошук кращих рішень (наука) та поширення кращих практик (освіта). Окремим питанням, окрім знаходження кращих рішень та поширення кращих практик менеджменту, $\epsilon$ здатність керівників проявити волю до перемоги та реалізувати прийняті рішення. Таким чином, професійна військова освіта має грунтуватись на принципах: системності, інтегрованості, динамічності, інноваційності, інституційності, відповідальності, організаційності, індивідуальності, легітимності, гуманістичної спрямованості, зв'язку 3 життям, співпраці, послідовності, науковості, наочності, доступності, інтерактивності, самостійності тощо. Вхідні та вихідні дані системи професійної військової освіти змінюються залежно від типу навчання. Принципи навчальної системи професійної військової освіти однакові для створення інструкторських занять, навчань чи академічних програм, а також для проведення та управління навчальною діяльністю.

Формування системи професійної військової освіти грунтується на системному підході, що передбачає врахування таких типових складових як: цільове призначення діяльності (результат-орієнтоване управління), спосіб організації діяльності (операційний/процедурний, процесний, проєктний, змішаний), ресурсне забезпечення та встановлення ролей і відповідальності, вимоги та обмеження, а також, вхідні дані/об'єкти. Врахування усіх частин направлене на забезпечення ефективності системи в цілому. Динамічність змін у сучасному світі, включно 3 військовою сферою, вимагає збільшення 
адаптивності і гнучкості системи підготовки особового складу, як і інших систем сектору оборони. Тобто актуальними є гнучкі умови впровадження результатів навчання, що впливають на процеси здобуття компетентностей військовими фахівцями (наприклад, зміни щодо набору та відбору, оперативних вимог, бюджетів чи закупівель обладнання можуть вплинути на систему підготовки військових фахівців). Безумовно, для досягнення освітніх цілей слід керуватися механізмом зворотного зв'язку, що дозволяє ефективно реагувати та адаптуватись у сучасних умовах. Підготовка фахівців на довгу перспективу стала нереалізовною і потребує заміни на підготовку особового складу протягом професійної кар'єри (формування людського капіталу протягом життя).

Сучасні підходи до організації менеджменту, засновані на системному підході і реалізовані у вигляді стандартів та рекомендацій, передбачають реалізацію повного перегляду архітектури системи освіти, з перепроєктуванням процесів діяльності, оцінюванням та розвитком спроможностей, забезпеченням діяльності відповідними ресурсами та постійним вдосконаленням (ризикорієнтована культура менеджменту).

В той час, коли індивідуальна підготовка призначена для задоволення потреб у кар'єрному розвитку особи, колективна підготовка фокусується на поєднаних навичках та знаннях, необхідних для підготовки військових формувань до бойового застосування. Колективна підготовка надає можливості підтримувати загальні знання, навички та можливості у військовій професії, набуті за допомогою індивідуальної підготовки та навчання (наприклад, щорічні індивідуальні стандарти бойових завдань), а також професійні знання, навички та можливості (наприклад, командно-штабні навчання), які дозволяють військовим фахівцям виконувати завдання. Колективна підготовка - це одночасне та послідовне виконання відповідних індивідуальних завдань у складі навчальних груп для отримання групових результатів. Колективна підготовка повторює або імітує оперативні умови, за яких передбачається виконання бойових завдань.

За наявної системи у військовому підрозділі кожний командир відповідає за колективну підготовку та звітування свого підрозділу про стан і бойову готовність військ, що відображає стратегічні вказівки щодо колективної підготовки та забезпечує детальний розподіл ресурсів для підтримки проектування, планування та проведення спільних, інтегрованих та комбінованих тренувань та навчань. Це спрямовує командирів підрозділів до непередбачених ситуацій, підтримує поточні зобов'язання та застосовує ресурси для забезпечення ефективного використання військового потенціалу.

Чергова зміна технологічного укладу проявляється через все більше використання роботизованих/автоматизованих систем для реалізації повсякденної діяльності. Існуючу систему все більше сприймають як анахронізм за якого людей неефективно використовують. А сучасна система менеджменту не існує поза концепції управління знаннями. Проявом сучасного стану технологічного розвитку $є$ парадокс значного зниження потреби у некваліфікованій робочій силі i високого рівня безробіття 3 нестачею 
мотивованих високопрофесійних кадрів. Для мотивованого особового складу невід'ємною складовою системи професійної військової освіти $є$ технологія дистанційного навчання. 3 іншого боку і стандартні вимоги є актуальними, а саме: військові навчальні заклади повинні бути забезпечені сучасними i перспективними зразками озброєння та військової техніки; державна система мобілізації та мобілізаційної підготовки повинна діяти на основі базових європейських підходів; має бути сформований військовий резерв, створено Єдиний державний реєстр військовозобов'язаних для забезпечення військового обліку громадян України, забезпечено ефективне функціонування системи підготовки резервістів та військовозобов'язаних; впроваджено раціональне співвідношення категорій особового складу сил оборони, створено ефективну систему управління кар'єрою військовослужбовців, забезпечено прозору та доброчесну систему добору, розстановки та призначення особового складу на посади [2].

Відповідно до зазначеного у Воєнній стратегії України переходу на програмно-проєктний підхід до розвитку спроможностей (реформування) та на виконання положень Стратегічного оборонного бюлетеня проєкти реформування освітньої сфери Державної цільової оборонної програми розвитку спроможностей мають передбачати: уточнення цілей та завдань системи професійної військової освіти, удосконалення системи законодавчого та іншого нормативного регулювання в цій сфері, перехід на систему освіти протягом служби, покращення ресурсного і інфраструктурного забезпечення освітньої діяльності, широке залучення кола стейкхолдерів до формування вимог та оцінювання рівня професійної підготовки в межах системи освіти, а також, уніфікацію вимог та архітектури системи військової освіти України до аналогічної системи країн-партнерів України [14].

Кожна країна світу має власні, історично складені і притаманні лише їй механізми реалізації кадрової політики у військовому середовищі. Ефективність реалізації кадрової політики залежить від фінансових можливостей держави, престижу військової служби в країні, іiі ролі й місця в суспільстві та конкурентоспроможності Збройних Сил на ринку праці держави, що забезпечує можливість підготовки кращих фахівців [12].

Впровадження прийнятих реформ $\epsilon$ складним та високовитратним процесом, оскільки військова сфера завжди була і $є$ однією з важливих статей бюджету будь-якої держави. Заходи, які спрямовані на досягнення цілей оборонної реформи, повинні бути забезпечені у межах видатків, визначених Законом України про Державний бюджет України на відповідний рік, а також можуть бути профінансовані додатково за рахунок благодійних внесків фізичних та юридичних осіб у порядку, визначеному Кабінетом Міністрів України, та з інших джерел, не заборонених законодавством.

На вітчизняному ринку праці тривалий час формувалася дуже низький рівень конкурентоспроможності діяльності у військовій сфері у порівнянні 3 іншими сферами діяльності, що мало прояв у вигляді недостатнього грошового забезпечення військових, недосконалої системи соціальних гарантій, наявності серйозних житлових проблем та відсутності впевненості щодо перспектив 
професійного та кар'єрного зростання, що в кінцевому випадку призвело до дестабілізації ситуації в Збройних Силах України та відпливу з них найбільш досвідчених та підготовлених військових фахівців за кордон або в інші сфери життєдіяльності суспільства.

На основі проведеного аналізу можна визначити такі напрями розвитку системи кадрового менеджменту в ЗСУ, як:

за напрямом "результати/потреби з освітньої діяльності": практик;

уточнення бізнес-моделі військової освіти на основі сучасних

уточнення цілей та мотиваційної складової організації освітньої діяльності;

за напрямом "організація освітньої діяльності":

реформи в системі кадрового менеджменту та запровадження нових форм, методів та механізмів реалізації кадрової політики;

повноцінне впровадження процесного підходу до побудови освітніх організацій загалом, проєктного підходу щодо реалізації реформування i постійного покращення та змішаного до проведення самих курсів;

за напрямом "ресурсне забезпечення освітньої діяльності":

удосконалення системи забезпечення освітньої діяльності викладацьким складом необхідного рівня;

широка автоматизація освітньої діяльності, включно 3 напрямом дистанційної освіти;

за напрямом “відбір/пошук кандидатів для освітніх програм":

удосконалення методів та форм залучення на військову службу України;

вдосконалення механізмів формування кадрового військового резерву;

вдосконалення системи відбору/добору кандидатів для проходження освітніх програм;

за напрямом "формування освітнього середовища":

розробка системи підготовки кадрів у відповідності до основних нормативно-правових актів у військовій сфері;

оптимізація соціального та гуманітарного забезпечення персоналу, адаптація військовослужбовців до цивільного життя.

Висновки та перспективи подальших досліджень. Таким чином, серед основних напрямів удосконалення освітньої діяльності для кадрового менеджменту в ЗСУ потребують:

- підготовка фахівців для кадрових служб ЗСУ на основі нових стандартів залучення, адаптації, проходження військової служби; запровадження кадрових технологій у відповідності до стандартів НАТО, приведення їх до світового рівня з метою подальшої інтеграції військової сфери України в єдиний європейський сектор безпеки;

- оптимізація механізмів державного управління військовою сферою та побудова на цих принципах кадрової політики в ЗСУ;

- удосконалення нормативно-правового забезпечення в галузі кадрової політики як на державному рівні, так і на рівні Міністерства оборони України; 
— належне фінансування потреб Збройних Сил України;

- розвиток соціального та ресурсного забезпечення військового відомства на рівні світових стандартів;

- розроблення оптимальної структури та визначення чисельності Збройних Сил України відповідно до потенційних можливостей держави, що визначатиме кадрову політику у військовій сфері та розміщення державного замовлення на підготовку військових спеціалістів.

Подальших досліджень потребують онтологічна модель системи професійної військової освіти, опис логічно-ієрархічної моделі освітніх спроможностей, підходи до адаптації сучасних освітніх технологій до потреб військової сфери, архітектурна модель та реалізація архітектурного циклу щодо системи військової освіти з врахуванням відповідних моделей НАТО та країнпартнерів, аналіз та адаптація сучасних практик кадрового менеджменту розвинутих країн до відповідної ситуації у сфері оборони в Україні.

\section{ЛІТЕРАТУРА}

1. Горбулін В. П. Світова гібридна війна: український фронт : монографія / за заг. ред. В. П. Горбуліна. - Київ : НІСД, 2017. - 496 с.

2. Гріненко О. І. Мобілізувати країну/О. І. Гріненко, О. П. Кутовий, М. І. Шапталеню// Оборонний вісн. ЦВІШБ. - Київ, 2017. - № 4. - С. 24 - 27.

3. Коваль О. В. Взаємозв'язки державної та військової кадрової політики як кадрового менеджменту на державному рівні у воєнній сфері / Коваль О. В. // Державне будівництво: зб. наук. пр. - Київ : НАДУ, 2017. - № 2. - С. 57 - 87.

4. Коваль О. В. Кадровий менеджмент на сучасному етапі реформування та розвитку Збройних Сил України / Коваль О. В. // Теорія і практика держ. упр. : зб. наук. пр. - Харків : Магістр, 2012. -Вип. 4(39). - С. 428 - 436.

5. Конституція України : Закон від 28 черв. 1996 р. № 254к/96-ВР. Режим доступу : https://zakon.rada.gov.ua/laws/show/254\%D0\%BA/96-\%D0\%B2\%D1\%80\#Text

6. Мартнненко В. М. Кадрова політика і державна служба : навч. посіб. / В. М. Мартиненко, Ю. В. Конотопцева, В. М. Щегорцова. - Харків : Магістр, 2013. - 208 с.

7. Політика забезпечення національної безпеки України в умовах позаблоковості : монографія / В. Ю. Богданович, І. С. Романченко, І. Ю. Свида, В. Б. Толубко. - Київ : ЦНДІ ЗС України, 2013. - С. 178 - 190.

8. Про військовий обов'язок і військову службу : Закон України від 25 березня 1992 p. Режим доступу : https://zakon.rada.gov.ua/laws/show/2232-12\#Text.

9. Про затвердження Інструкції з організації обліку особового складу Збройних Сил України : наказ Міністерства оборони України від 26 травня 2014 р. № 333. Режим доступу : https://zakon.rada.gov.ua/laws/show/z0611-14\#Text.

10. Про затвердження Положення про військові комісаріати : Постанова Кабінету Міністрів України від 3 червня 2013 року № 389. - Режим доступу : https://zakon.rada.gov.ua/laws/show/z0611-14\#Text.

11. Про затвердження Порядку організації та ведення військового обліку призовників і військовозобов'язаних: Постанова Кабінету Міністрів України від 7 грудня 2016 року № 921. -Режим доступу : https://zakon.rada.gov.ua/laws/show/921-2016-\%D0\%BF\#Text.

12. Сивак О. І. Кадрова політика та ії роль у реформуванні Збройних Сил України : автореф. дис. ... канд.. політ. наук: 23.00.02 / Сивак Олександр Іванович. - Київ, 2007. - 19 с.

13. Стратегія національної безпеки України, яка затверджена указом Президента України від 14 вересня 2020 року № 392/2020. Режим доступу : https://www.president.gov.ua/documents/3922020-35037.

14. Стратегічний оборонний бюлетень України, який затверджений указом 
Президента України від 17 вересня 2021 року № 473/2021. Режим доступу : https://www.president.gov.ua/documents/4732021-40121.

\section{REFERENCES}

1. Horbulin V. P. Svitova hibrydna viina: ukrainskyi front : monohrafiia / za zah. red. V. P. Horbulina. - Kyiv : NISD, 2017. - 496 s.

2. Hrinenko O. I. Mobilizuvaty krainu/O. I. Hrinenko, O. P. Kutovyi, M. I. Shaptaleniu// Oboronnyi visn. TsVIShB. - Kyiv, 2017. - № 4. - S. 24 - 27.

3. Koval O. V. Vzaiemozviazky derzhavnoi ta viiskovoi kadrovoi polityky yak kadrovoho menedzhmentu na derzhavnomu rivni u voiennii sferi / Koval O. V. // Derzhavne budivnytstvo: zb. nauk. pr. - Kyiv : NADU, 2017. - № 2. - S. 57 - 87.

4. Koval O. V. Kadrovyi menedzhment na suchasnomu etapi reformuvannia ta rozvytku Zbroinykh Syl Ukrainy / Koval O. V. // Teoriia i praktyka derzh. upr. : zb. nauk. pr. - Kharkiv : Mahistr, 2012. -Vyp. 4(39). - S. 428 - 436.

5. Konstytutsiia Ukrainy : Zakon vid 28 cherv. 1996 r. № 254k/96-VR. Rezhym dostupu : https://zakon.rada.gov.ua/laws/show/254\%D0\%BA/96-\%D0\%B2\%D1\%80\#Text

6. Martnnenko V. M. Kadrova polityka i derzhavna sluzhba : navch. posib. / V. M. Martynenko, Yu. V. Konotoptseva, V. M. Shchehortsova. - Kharkiv : Mahistr, 2013. - 208 s.

7. Polityka zabezpechennia natsionalnoi bezpeky Ukrainy $\mathrm{v}$ umovakh pozablokovosti : monohrafiia / V. Yu. Bohdanovych, I. S. Romanchenko, I. Yu. Svyda, V. B. Tolubko. - Kyiv : TsNDI ZS Ukrainy, 2013. - S. 178 - 190.

8. Pro viiskovyi oboviazok i viiskovu sluzhbu : Zakon Ukrainy vid 25 bereznia $1992 \mathrm{r}$. Rezhym dostupu : https://zakon.rada.gov.ua/laws/show/2232-12\#Text.

9. Pro zatverdzhennia Instruktsii $\mathrm{z}$ orhanizatsii obliku osobovoho skladu Zbroinykh Syl Ukrainy : nakaz Ministerstva oborony Ukrainy vid 26 travnia 2014 r. № 333. Rezhym dostupu : https://zakon.rada.gov.ua/laws/show/z0611-14\#Text.

10. Pro zatverdzhennia Polozhennia pro viiskovi komisariaty : Postanova Kabinetu Ministriv Ukrainy vid 3 chervnia 2013 roku № 389. - Rezhym dostupu : https://zakon.rada.gov.ua/laws/show/z0611-14\#Text.

11. Pro zatverdzhennia Poriadku orhanizatsii ta vedennia viiskovoho obliku pryzovnykiv i viiskovozoboviazanykh: Postanova Kabinetu Ministriv Ukrainy vid 7 hrudnia 2016 roku № 921. Rezhym dostupu : https://zakon.rada.gov.ua/laws/show/921-2016-\%D0\%BF\#Text.

12. Syvak O. I. Kadrova polityka ta yii rol u reformuvanni Zbroinykh Syl Ukrainy : avtoref. dys... kand.. polit. nayk: 23.00.02 / Syvak Oleksandyk Ivanovych. - Kyiv, 2007. - 19 s.

13. Stratehiia natsionalnoi bezpeky Ukrainy, yaka zatverdzhena ukazom Prezydenta Ukrainy vid 14 veresnia 2020 roku № 392/2020. Rezhym dostupu : https://www.president.gov.ua/documents/3922020-35037.

14. Stratehichnyi oboronnyi biuleten Ukrainy, yakyi zatverdzhenyi ukazom Prezydenta Ukrainy vid 17 veresnia 2021 roku № 473/2021. Rezhym dostupu : https://www.president.gov.ua/documents/4732021-40121.

\section{РЕЗЮМЕ}

Виталий Рахманов, доктор педагогических наук, доцент Национальный университет обороны Украины имени Ивана Черняховского

Сергей Яценко

кандидат технических наук Национальный университет обороны Украины имени Ивана Черняховского 


\section{Усовершенствование образовательной деятельности для кадрового менеджмента в Вооруженных Силах Украины}

В статье рассматриваются предложения по обеспечению качественным персоналом в Вооруженных Силах Украины, усовершенствование образовательной деятельности в контексте оборонной, кадровой и других реформ, с учетом современных международных и военных факторов, влияющих на формирование дееспособной армии Украиньл. Основное внимание сосредоточено на формировании кадрового менеджмента в ВСУ. В статье акцентировано внимание на том, что на отечественном рынке труда долгое время формировалась низкая конкурентоспособность военной сферы вследствие недостаточного обеспечения военных, несовершенной системы социальных гарантий, наличия жилищных проблем и отсутствия уверенности в перспективах профессионального и карьерного роста, что в конечном случае приведет к дестабилизации ситуации в Вооруженных Силах Украины и утечки из них наиболее опытных и подготовленных военных специалистов за границу или в другие сферы жизнедеятельности общества. Авторами сделан вывод о том, что в дальнейших исследованиях требуется онтологическая модель системы профессионального военного образования, описание логически-иерархической модели образовательных возможностей, подходьл $\kappa$ адаптации современных образовательных технологий $\kappa$ потребностям военной сферы, архитектурная модель и реализаџия архитектурного иикла системы военного образования с учетом соответствующих моделей НАТО и странпартнеров, анализ и адаптация современных практик кадрового менеджмента развитых стран к соответствующей ситуачии в сфере обороны в Украине.

Ключевые слова: кадровый менеджмент; образовательная деятельность; оборонная реформа; профессиональное военное образование, системный подход

\section{SUMMARY}

Vitaliy Rakhmanov,

Dr. (Pedagogical Sciences), associate professor

National Defense University of Ukraine named after Ivan Chernyakhovskii

Sergey Yasenko,

$\mathrm{PhD}$ (technical sciences),

National Defense University of Ukraine named after Ivan Chernyakhovskii

\section{Improvement of educational activities for personnel management in the Armed Forces of Ukraine}

The article considers proposals for providing quality personnel in the Armed Forces of Ukraine, improving educational activities in the context of defense, personnel and other reforms, taking into account current international and military factors influencing the formation of a capable army of Ukraine. The main focus is on the formation of personnel management in the Armed Forces. The article emphasizes that the domestic labor market has long been characterized by low military competitiveness due to insufficient military support, imperfect social security system, housing problems and lack of confidence in the prospects for professional and career growth, which will ultimately lead to destabilization of the situation in the Armed Forces of Ukraine and the outflow of the most experienced and trained military specialists abroad or in other spheres of society. The authors conclude that further research is needed on the ontological model of vocational military education, description of the logical-hierarchical model of educational capabilities, approaches to adapting modern educational technologies to the needs of the military, architectural model and implementation of the architectural cycle of the military education system 
NATO and Partner countries, analysis and adaptation of modern personnel management practices of developed countries to the relevant situation in the field of defense in Ukraine.

Key words: personnel management; educational activities; defense reform; professional military education; systematic approach. 